\title{
On Location at a Nonentity: \\ Reading Hollywood's "Micronesia"
}

\section{David W Kupferman}

But Roche, imagining the sunset soon to come, the hills and the royal palms against the evening sky, thought: It is, after all, very beautiful. It is a pity I've never seen it like this, and have never enjoyed it.

-V S Naipaul, Guerrillas

\section{Cold Open}

Owen Wilson thinks "Micronesia" is funny. He has picked up on the notion that Micronesia serves as a suitable Other, while seemingly provoking a "Where on earth is that?" reaction from the mainstream moviegoing audience. He references Micronesia in the Ben Stiller comedy Zoolander (200I) by announcing to the guests at his house, "Hey, everybody! Listen up for a second. Derek and Matilda are hiding 'cause some dudes brainwashed Derek to off the prime minister of Micronesia." The plot of that film, however, involves the planned assassination of the prime minister of Malaysia; but since Malaysia and Micronesia both start with " $M$ " and end similarly, what's the difference? (For what it's worth, Micronesia doesn't have a prime minister.) The joke, extra-diegetically (that is, outside the film's narrative), is that while Owen Wilson's character Hansel is a dimwitted male supermodel who wouldn't know the difference between the two locales, would the audience know either? Again in Wedding Crashers (2005), Wilson's character, in an attempt to score with the daughter of the secretary of the treasury, tells the secretary (played by Christopher Walken) during a wedding reception, "I just wanted to say how much I appreciated your position paper on economic expansion in Micronesia.”

The Contemporary Pacific, Volume 23, Number I, I4I-I 68

(C) 201 I by University of Hawai'i Press 
The secretary replies incredulously, "You've read my position paper?"the joke in this case being the assumption that Wilson's or Walken's character (again, let alone the audience) knows anything about Micronesia. Indeed, I am tempted to suggest that what the secretary really wanted to ask both Wilson's character and the audience is "You know where Micronesia is?"-never mind whether they know the prospects for its economic (or any other kind of) development.

Unfortunately, for Micronesia at least, Wilson is not alone in making the region the butt of cinematic jokes. In the 2008 Martin Lawrence vehicle Welcome Home Roscoe Jenkins, Martin as the title character returns from his television career in Hollywood to his boyhood home in the Deep South, bringing with him his fiancée Bianca, the champion of a recent season of Survivor. Specifically, Bianca won on Survivor: Kiribati, a location chosen probably for its exotic-sounding name; to the ears of anyone familiar with that country, or with Micronesia in general, the way the characters in the film pronounce its name is jarring: "Kiribatee." The (intentional?) ignorance conveyed by this minor detail resurfaces as Roscoe's family members, initially smitten with the idea of Bianca's triumph on "Survivor: Kiribatee," soon sour on her and begin to refer to her as "Survivor Kiribatee my ass." Rather than make the least effort to learn anything about Kiribati, even the proper pronunciation of the country's name, the filmmakers, actors, editors-in short, the professional culture-makers-and by extension the audience, perpetuate the mispronunciation, albeit most likely without realizing it. "Kiribatee," functioning as a representation of the exotic-so exotic, in fact, that it is the setting for a (fictional) season of Survivor-symbolizes what is so often true about representations of the Pacific: that it is a place of colonial screen, de-territorialized, de-historicized, and completely acontextual. In the case of the actual Survivor series, Micronesia exists as a backdrop, notably in the 2005 season, filmed in Palau and aptly named Survivor: Palau, and again in the 2008 season, also filmed in Palau but this time masked and re-exoticized as Survivor: Micronesia. It exists for Owen Wilson and for all the characters in Welcome Home Roscoe Jenkins as the ignorant punch line to an uninformed joke; and it exists for Hollywood, I argue, as a space that is displaced even from itself. Micronesia as a region, and its individual components as singular islands, is a pan-Pacific everywhere, while at the same time it exists nowhere. It is a cinematic utopia; it is a cinematic nonentity.

Not that there are a lot of studio films set in or about or even remotely referencing Micronesia. Aside from the World War II set pieces Hell to 
Eternity (1960), about the battle for Saipan, and No Man Is an Island (1962), set on Guam (but filmed in the Philippines using Filipina and Filipino actors), ${ }^{1}$ Micronesia is a difficult subject to locate in feature film. It is implied in the plot of the original Gojira (1954), in which US nuclear testing in the Pacific results in the creation of the Tokyo-smashing dinosaurlizard; in the original Japanese version of the film, in fact, a significant plot point involves the tragedy of the fishermen aboard the fishing vessel Lucky Dragon caught in the nuclear fallout from the hydrogen bomb test carried out by the United States on the Marshallese atoll of Bikini. However, no specific mention is made of the Marshall Islands, as the story focuses on the effects of nuclear testing on the Japanese, most likely in relation to the then-recent experiences of Hiroshima and Nagasaki, and the American version of the film-released two years later as Godzilla, King of the Monsters! with Raymond Burr now in a starring role (or rather, edited into the original Japanese version)—skirts the ethical issue of US responsibility in the nuclear testing program altogether.

More recently, Guam has served as the setting for the Spanish horror film Arachnid (200I) and the fledgling Guam Motion Pictures Company's Max Havoc: Curse of the Dragon (2004), both of which were made for distribution direct to DVD. More relevant to actual island experience, Morning Comes So Soon (2008) centers on Chinese-Marshallese relations in the Marshall Islands. However, none of these recent films are big-budget studio productions (although Morning arguably qualifies as what Gilles Deleuze calls "minor cinema"); they are likely never to become blockbusters but rather to reach smaller, more specialized audiences. It is much easier to locate documentaries about the region, such Radio Bikini (I988), which is about the nuclear testing in the Marshall Islands and was nominated for an Oscar for best documentary feature. ${ }^{2}$ But where does one locate Micronesia as imagined by Hollywood—and thus by significant numbers of the moviegoing public, whose understanding of the region is largely informed by popular images of the islands? Indeed, how does Micronesia as a subject factor into the American cinematic imaginary?

For that matter, what does "Micronesia" mean? Depending on one's perspective (political, cultural, historical), the term can describe a variety of entities and mutable boundaries that often shift with one's purpose and agenda. As David Hanlon suggested, "For the most part, Micronesia has existed only in the minds of people from the outside who have sought to create an administrative entity for purposes of control and rule" (I989, I). More recently and somewhat less elegantly, Hanlon would have us ask, 
“'Where, and what the hell is Micronesia??" (2009, 9I)—or, to repeat a joke from the Trust Territory period that gained popularity in the I960s, "Mike who?"

The term "Micronesia" was first applied to an area of the Pacific in I 832 by the French explorer J S C Dumont d'Urville in a paper he delivered to the Sociéte de Géographie, although it is perhaps important to note that Dumont d'Urville plagiarized the term from an unpublished paper written a few months earlier by a rival, G L Domeny de Rienzi (Tcherkézoff 2003). Of the variety of interpretations of the term's original purpose, Serge Tcherkézoff posited that Micronesia, like its cousins Melanesia and Polynesia, is a construct of and constructive of racial differentiation deployed by European navigators on the people of the region. While Melanesians were considered dark-skinned and therefore undesirable, the lighter-skinned Polynesians were seen to inhabit the "paradise" of the Pacific; Micronesians, thought of as a spin-off from Polynesians geographically as well as racially, occupied a space somewhere in between. Paul Rainbird argued that Micronesia is a construct of absence (in relation to Polynesia): absence of taboo, of common language, and of Dumont d'Urville's understanding of the region (Rainbird 2003). In any case, it is not clear what Micronesia is, as it has consistently been constructed by what it is not, a sort of Micronesia-as-absence. Indeed, we can consider the writing and reading of Micronesia as an exercise defined by absence of region, of borders, of the entity itself. As Jacques Derrida reminded us, "A text is not a text unless it hides from the first comer, from the first glance, the law of its composition and the rules of its game" (I98I, 63). Taking Micronesia as our text, it is instructive to consider the "rules of its game" (if in fact there are any); more specifically, we ought to consider how Hollywood inscribes Micronesia's rules of its game.

What is important, then, is not so much what Micronesia is, but rather what it means. Put another way, we would do well to ask whether "Micronesia" is even a relevant or appropriate term to use; for example, do Pohnpeians consider themselves Micronesian in the same way that Nauruans do? For the purposes of the current discussion, how does Hollywood subjectify the islands of Micronesia? What are the "truths" about Micronesia that Hollywood produces, and what are their functions? Fortunately, three films, each from a different era and each concerned with (de)positioning the islands in the region, offer a lens through which we can locate Micronesia in the broader cinematic lexicon. By critically reading His Majesty O'Keefe (1953), starring Burt Lancaster and set in Yap; 
Nate and Hayes (1983), starring Tommy Lee Jones and located partially in Pohnpei; and Windtalkers (2002), starring Nicholas Cage and situated in a re-imagined battle of Saipan, I intend to locate "Micronesia" as it is romanticized, demonized, or just plain ignored, in order to demarcate what is displaced by such conditions of representation and to consider the effects of that displacement. Reading these films will offer a clearer picture of how "Micronesia" as a discursive construction operates cinematically in a way similar to that first espoused by Dumont d'Urville: that the meaning of the term "Micronesia" and the rules of its game are determined by those who define them.

Gilles Deleuze offered two useful cinematic analytics: that of the American historical film and that of realism and its consequent potential for fabulation (I986). To the first analytic, and considering that all three of our films are to some degree historically based, it seems appropriate to bear in mind Deleuze's analysis of Nietzschean aspects of history and their application to the cinema: "monumental history," which concerns the rise, fall, and interaction of civilizations; "antiquarian history," which runs parallel to monumental history and focuses on the clash of civilizations and individuals as well as the "appearance" of historical reconstruction; and "ethical history," which requires judgment in order to facilitate an improved order (Nietzsche 1997). Moreover, it is important to keep in mind that Nietzsche's analysis was a critical one, in that he took issue with what he concluded were attempts at historiography that distracted one from achieving one's own becoming, or, in Nietzschean terms, one's "will to power." These three aspects of history emerge at various moments in each of the three films examined here, with the effect of providing a lens through which we can determine how the historicity of plots and representations treats the islands of Micronesia, and how it works through the cinematic image to deny the islands' will to power.

With regard to realism, Deleuze told us that "derived milieux assert their independence and start to become valid for themselves. Qualities and powers are no longer displayed in any-space-whatevers, no longer inhabit originary worlds, but are actualised directly in determinate, geographical, historical and social space-times" (I986, I4I). That is, cinematic realism is interested in constructing and exhibiting ordered sets of actions and emotions through a governable body in a place, time, and milieu that can be located in the image; for our purposes, this embodiment of realism lies in the image of Micronesia. But this image offers little to which Islanders themselves can relate and alienates the cinematic subject of Micronesia 
from itself. Nowhere in these films do the islands of Micronesia have the opportunity to speak for themselves or to will themselves to any kind of self-constructing enunciation. Rather, David Rodowick's I 997 reading of Deleuzean fabulation offers an alternative approach through which minor cinema, perhaps beginning with the example of Morning Comes So Soon as well as others, can play a role in inverting Hollywood's Micronesian realism by providing a more complex lexicon than the exotic backdrop of the colonial screen. Fabulation as a process, according to Rodowick, necessitates that "an idea or image must be constructed through which a people can affirm their becoming as a collective will to power" (I997, I 56). In other words, "fabulation" - a term used by Deleuze to mean the "storytelling function," or rather act, of film-offers a vehicle through which a philosophical (and not necessarily a demographic) minority defines itself against and "through the forces of domination and exclusion that occlude it" (Rodowick 1997, I 53). While it is difficult to conceive of such a collective enunciation of will to power emerging from the mispronunciation of island names or engagement in a series of geopolitical non sequiturs, the consequences of place and conditions of representation in the social imaginary require that we learn to read Hollywood's Micronesia in order to facilitate the replacement of a cinematic nonentity with one built on more than just its absence.

\section{Carpetbagger in Paradise: His Majesty O’Keefe (I953)}

At the end of The Man Who Shot Liberty Valance (1962), Jimmy Stewart's character tells a newspaper editor that he in fact did not shoot the outlaw Liberty Valance, and that his rise to fame and political power was built on a lie. On hearing this, the editor destroys his notebook and tells Stewart, "When the legend becomes fact, print the legend." This same philosophy in reporting has apparently been applied to the "history" of David Dean O'Keefe, the title character in the 1953 Burt Lancaster vehicle His Majesty O'Keefe. Briefly, O'Keefe was an Irishman who moved to Savannah, Georgia, in his twenties, ran ships for the Confederacy during the Union blockade of the Atlantic coast, ran away from Savannah after the war to avoid the law after mistakenly thinking he had killed a fellow sailor, found himself involved in the copra trade sailing between Micronesia, Melanesia, and Southeast Asia, and ended up settling on the island of Yap where he had figured out how to expedite the quarrying and transfer of stone money (which the Yapese call rai) from Palau. Based on a novel of 
the same name by Lawrence Klingman and Gerald Green (I950), the film His Majesty O'Keefe takes rather generous liberties with these "facts" of O'Keefe's life and times in Yap, compounding a similar problem in the original novel. Indeed, the story of O'Keefe as well as a number of other colorful characters who have come to populate the popular historical imaginary of Micronesia has become so conflated with myth, legend, and hearsay that it is probably impossible to tell fiction from fact-or perhaps more correctly, how particular "truths" function. And so people continue, academically and cinematically, to "print the legend."

In a recent article Francis Hezel admitted as much when he said, "I was obliged to refer to Klingman and Green's half-fictional account twentyfive years ago as I was writing my history of precolonial Micronesia" $(2008,240)$. It is a rare thing to encounter a historian who admits to printing the legend as told by a third party, let alone someone like Hezel, who has had arguably the greatest contemporary impact on the development of popular Micronesian history. Indeed, one only need look at Hanlon's 2006 assessment of Hezel's 1983 volume, The First Taint of Civilization (the "history of precolonial Micronesia" mentioned above) to appreciate both the book's commercial success and its sway over defining widespread notions of what Micronesian history is and means. What is more troubling is that the intent of Hezel's article is to "attempt to rescue O'Keefe from the tangle of legends and half-truths that grew up around him" (2008, 240 ), especially when it then proceeds to offer even more half-truths as a sort of historical melioration. For example, Hezel's article asserts that one of O'Keefe's daughters was illegitimate; however, his source for this tidbit was an interview (not conducted by Hezel) with one of O'Keefe's granddaughters (from one of the presumably more legitimate daughters). The point here, however, is not to discredit Hezel or his source in Klingman and Green; it seems too difficult a task to get at the "facts." Rather, what we should be concerned with is the way in which the novel has shaped the "monumental history" of O'Keefe both as written by Hezel and as presented in film.

Indeed, if we are to briefly consider how Klingman and Green (echoed by Hezel) constructed and essentialized the Yapese, we may have a better foundation with which to read the cinematic account. At the conclusion of their tale, Klingman and Green wrote, "Despite all the efforts of successive occupying powers, the stubborn Yaps have remained the same. They refuse to work for the new nobichay [Yapese word for foreigners, currently spelled ngabchey]; they are indifferent to [the foreigners'] culture, 
with the exception of soft drinks and cigarettes" (I950, 353). One may be inclined to excuse the rather harsh terms used here to characterize Yapese, but then what is one to do with the following passage by Hezel? "Motivating Yapese to engage in production for foreign traders had always been a challenge, for the people never exhibited the passionate desire for Western goods (alcohol and tobacco excepted) that people from most other islands displayed. The Yapese were stubbornly proud of their traditions" (Hezel 2008, 243). Although Hezel's much more recent use of the term remains a disconcerting mystery, the word "stubborn" may be the best we can expect from Klingman and Green; more often, channeling the fictional O'Keefe, their account consistently refers to the Yapese as "lazy," "savage," and "children" (I950). What is more, we see that Yap, and by extension Micronesia, is geographically constructed as a rather insignificant site. Even Hezel wrote of "the small island of Yap" (2008, 242), while Klingman and Green described the islands of Micronesia as "scattered like crumbs on a tablecloth" (1950, I9). Thus, in these accounts of Yap, mediated as they are through the story of David O'Keefe, both the people and the island are portrayed as trivial and generally inconsequential.

Just how inconsequential, however, is most clearly seen through a reading of the story as presented in film. It is perhaps best to state the obvious: the "Yapese" in His Majesty O'Keefe are in fact played by Fijians. For a student of the Pacific, this convenient substitution of one group of Islanders for another is both unsettling and problematic-unsettling because it betrays a general ignorance about the region on the part of both Hollywood and its audience, and problematic because it erases the whole multiplicity of cultures, histories, and geographies that make up Pacific Islands societies. Bearing in mind the Deleuzean analytic of monumental history, "such an aspect of history favours the analogies or parallels between one civilisation and another" (Deleuze I986, I49), it is perhaps of minor consequence that Fiji and Yap actually have little in common other than coconuts and beaches, and even that much is arguable depending on where in each island group one finds oneself. But culturally, linguistically, and historically, Yap and Fiji are about as interchangeable as France and Greece-that is to say, they are not transposable in any meaningful way. However, in this case, and in others to be discussed later, one set of islands is as good as any as far as Hollywood's historical and cartographic conceptions are concerned-and as long as there are blue skies and bluer waters, what's the difference?

A rather important difference must be teased out, considering our inter- 
est not only in what is represented through such filmic images but also in what is produced by them and dispersed into the social imaginary. With the important exception of three characters to be mentioned shortly, every "Yapese" Islander speaks Fijian, drinks kava, and otherwise engages in activities that have nothing to do with the actual island of Yap. This would be the equivalent of setting a movie about Paris in the city of Athens, using a Greek cast who all speak in the vernacular (and who no doubt would refer to the "Eiffel Tower" while pointing at the Acropolis). The three "Yapese" characters who interact with O'Keefe in ways that are necessary to move the plot forward are played by the Burmese-Jewish actor Abraham Sofaer (as Fatumak, the Yapese "medicine man," for lack of a better term); the Jamaican-British actress Tessa Prendergast (as the love interest Kakofel); and the African-American dancer and actor Archie Savage (as Boogulru, the "chief" of Yap and O'Keefe's main island rival). As Fatumak, Sofaer stands out among the other "Yapese" because he wears a suitably curly wig and extended prosthetic earlobes, and because he is swathed in brown body paint that can best be described as "Melanesian face." When O'Keefe meets Fatumak, introduced through their mutual friend, the German trader Alfred Tetens, O'Keefe is surprised to learn that Fatumak knows English. He says, "You speak English," to which Fatumak replies, "Thanks to my good friend Herr Tetens." What is particularly grating about this exchange, however, is that Fatumak speaks English with a heavily affected British-Raj accent, leaving us to wonder how it is that a German taught a "Yapese" to speak like a British colonial stationed in Burma. In addition, Lancaster, displaying difficulty getting over his own East Coast accent, insists on pronouncing copra as "cahpra" (a pattern of mispronouncing Pacific terms that has lasted at least through Martin Lawrence's recent mangling of "Kiribatee"), even while the rest of the characters, including Tetens and Fatumak, pronounce copra correctly.

For her part, Kakofel does not speak; she merely looks coyly at O'Keefe, hinting at a secret love affair (which is much more explicit in Klingman and Green's written account than would have been permissible in film by Hollywood standards of the mid-I950s). Yet even in the film, Kakofel, symbolic of all "Yapese" women (with the exception of her relative lightness of skin compared to the Fijian women seen in the background), is emblematic of what Teresia Teaiwa called the marginalization of "s/ pacific bodies" (2000): Hollywood's mediation of the ideal island woman as silent, sexual, acquiescent, and dressed in grass skirt and coconut bra. As Bosley Crowther wrote in a 1954 New York Times review of the film, 
"Tessa Prendergast looks mighty fetching as a speechless but eloquent native girl." It is no secret that Yapese women to this day customarily dress only in long skirts while baring their breasts. Film censors in the I950s would not have permitted such an improper, if accurate, portrayal of actual Yapese culture, but it is interesting to note that Lancaster spends most of the first half of the film shirtless (and appears the same way on the promotional film poster and current DVD cover)—displaying almost an inversion of gender dress codes between Yapese women and Western men. The last scene of the film completes this inversion of Western and Yapese cultural norms and protocols as O'Keefe brazenly embraces his young bride, Dalabo, and kisses her in front of the village to celebrate his triumph over the German colonists. The "Yapese" erupt in cheers, and the villagers rejoice in a way that, even today, would be considered a rather unseemly validation of a display of public affection between the sexes. For an American audience, of course, this type of ending is perfectly acceptable, and it seems to signal the rogue American's conquest over both the foreign interlopers (the Germans) and the natives.

The clichéd backdrops and the use of pan-Pacific props during pivotal dancing and battle scenes are almost too obvious to consider here, except to say that the use of Pacific stereotypes-a mishmash of tiki figures, spears adorned with feathers, and mute "Yapese" chiefs (led by Boogulru) who communicate by hitting themselves in the chest with their fists-is reminiscent of Edward Said's critique of the West's mediation and production of Orientalism (or perhaps here "Pacificism") and the subsequent "free-floating mythology of the Orient" (Said I978, 53). Indeed, there seems to be an unintentional effort to conflate all the thousands of islands in the Pacific as somehow uniform, romantic, and immanently essentializable. As a case in point, an obituary of the actress who played Kakofel reported, "In the I950s, Tessa Prendergast became an actress, landing the role of the Tahitian love interest opposite Burt Lancaster in His Majesty O'Keefe" (Telegraph 200I; emphasis added). Thus there is no discernible difference in the social imaginary between Yap, Fiji, and Tahiti; all Pacific Islands are interchangeable.

So while His Majesty O'Keefe is ostensibly, although loosely, based on the life and times of David O'Keefe, it is also about the erasure of its cinematic location. And while it "takes place" on Yap, the film (following Klingman and Green's novelistic account as well as Hezel's history) really employs the Hollywood trope of representing a foreign land and people through the story of a white American man regarded as "the hero"-a 
method used to varying effect in the other films considered later in this piece. Although secondary to the development of the film, this displacement of Yap, and in fact all of the Pacific, can be seen in moments both large and small, such as when O'Keefe travels to "Palau" and finds Islanders who look strikingly similar to their "Yapese" counterparts (since all the island extras are Fijian) and who also speak the same language (Fijian); or in the opening moments of the film when the filmmakers attempt to orient us amid this sea of islands by offering a discursive introduction to the location. The on-screen text reads, in part, "This entire picture was photographed in the South Pacific ... where for years the basic economy and wealth revolved around the dried meat of the coconut ... known as 'copra.' ... And on the island of Yap the natives worshipped an exotic, sacred stone they called ... 'fei." And right after identifying the location as "Yap" (which technically does not lie in the South Pacific, as it is north of the equator), the text notes: "We wish to acknowledge our gratitude to the Secretary for Fijian Affairs; to Ratu Penaia Lala Latianara, Serua District Chief in Charge, and to the wonderful people of the Fiji Islands." This suggests that "Yap" may not even exist.

Yet it does exist, and in a final act of geographic dislocation, the camera closes in on a map of the Pacific, with the islands of Yap highlighted and the text "Yap" boldly displayed while Lancaster's voice-over intones, "South Seas, I870. Center of the copra trade" (except, of course, that Lancaster pronounces it "cahpra"). This explicit use of a map to orient the audience to a specific place, Yap, in fact has the opposite effect, since it comes immediately after the filmmakers' admission that the film was shot in Fiji. The role of the map here serves a rather different purpose, as Tom Conley stated: "Viewers of maps who seek to arrive at a destination often discover that, once their states of agitation and expectation are accounted for, they are in different places at once" (2007, I 5). And what more different destination could the viewer arrive at than Yap, especially after learning that the film was shot entirely in Fiji? It is precisely in this contradictory cartography that we are able to discern two things: First, "the map can reveal why and how it [the film] is made and how its ideology is operating" (Conley 2007, 20) -in this case the history and ideology of the film are quite clear from the confession that the action takes place somewhere else, but that the two locations are considered essentially the same in geography, demography, and representation. Second, this conflation of island cultures becomes a sort of "truth" in the social imaginary; as Conley noted, "When a map appears in a movie it often turns an oth- 
erwise coded and controlled image into a lacunary [empty, missing] or isolated 'fact'" $(2007,20)$. Thus the brief image of the map of Yap, while dislocating the viewer from the previous written narrative on the screen, at the same time allows the filmmakers to declare that Yapese are Fijians, that cultural differences do not matter, and that all islands in the Pacific are the same. In short, "Yap" is nothing more than an arbitrary placeholder on a map and is therefore a cinematic nonentity.

\section{The Bully Pulpit: Nate and Hayes (1983)}

While His Majesty O'Keefe opens with a peaceful Islander in the background weaving a coconut frond on the white sand beach as blue water washes ashore, suggesting a rather innocuous and idyllic island existence, a similar beach setting for Nate and Hayes (1983) is disrupted by the rather ominous figure of a black crab crawling menacingly to the cadences of a dark, dissonant musical overture. This contrast in opening images and sequences offers a rather useful reading of the main points about "Micronesia" in the two films: in the first, the islands and Islanders are docile and easily conquered; in the second, they are dangerous and to be feared (so feared, in fact, that the British title of the second film is Savage Islands, which is also how the film is listed in Mawyer 1998). Indeed, the demonization of Micronesia and Micronesians in Nate and Hayes is so overwhelming and offensive that if there were an Academy Award for what Said called "imaginative geography," this film would have won peerlessly. As Said stated, "imaginative geography and history help the mind to intensify its own sense of itself by dramatizing the distance and difference between what is close to it and what is far away" (I978, 55)-and the Islanders portrayed in this film are about as far away from their own sense of themselves as conceivably possible.

To begin, however, as in the case of David O'Keefe, we should briefly consider the legend that is William "Bully" Hayes (one of the title characters) and his continuing legacy in Micronesia. As with O'Keefe, there is little "history" about Hayes that can be verified; Hayes's legend also seems to suffer from the Liberty Valance effect, though with mixed results. Known as a pirate, buccaneer, scalawag, and blackbirder, Bully Hayes is probably the most notorious nineteenth-century American in the Micronesian social imaginary, and nowhere is that more palpable than in Kosrae, where Hayes purportedly buried his stolen gold and treasure in the mountains of the southern part of the island after the destruction of his ship, 
the Leonora, in Utwe Harbor. To this day Kosraeans from the village of Malem almost proudly claim direct descent from Hayes, and the Pacific Treelodge Resort has recently reopened its restaurant, now called Bully's Restaurant. Hayes's legend, it seems, continues to be printed.

But historically, Hayes is perhaps best known for his rather enthusiastic engagement in blackbirding. In his recent book on the slave trade in the Pacific, Gerald Horne devoted an entire chapter to Hayes, describing him as "the consummate blackbirder of U.S. origin" $(2007,52)$. In Rascals in Paradise, a popular history by James Michener and A Grove Day, Hayes is also profiled in his own chapter; the authors depict his involvement in the blackbirding trade as "a new kind of adventure that would account for his principal fame throughout the Pacific" (I957, 235). Even cinematically, Hayes makes an appearance in His Majesty O'Keefe; Hayes beats O'Keefe in a bar fight in Hong Kong, but O'Keefe later thwarts Hayes's plans for enslaving the Islanders on "Yap" by giving him a well-deserved thrashing during an attempted slave raid on the island.

Considering this history, then, even as it exists in the popular imaginary of Micronesia, Michener and Day's I957 work, and an earlier cinematic portrayal, it is difficult to understand how the Bully Hayes of Nate and Hayes can exhibit such scruples when it comes to blackbirding. The film goes so far as to illustrate Hayes's disdain for the practice, as in the scene when his ship picks up the missionary Nathaniel Williamson (the Nate of the title) whose fiancée, Sophie, has just been kidnapped during a blackbirding raid on an unnamed Pacific Island. Nate accuses Hayes of pillaging the island, screaming, "What did you do to her, you blackbirder?" One of Hayes's crew slaps Nate's face, retorting, "He [Hayes] ain't no blackbirder!" Hayes, played by Tommy Lee Jones, then chimes in, "You've got the wrong man, Reverend. There's no blackbirds and no Sophie aboard this ship." To a degree not seen in the example of O'Keefe, this cinematic portrayal of Bully Hayes inverts the limited historical record, making a known slave trader into the slave trade's sworn enemy and in effect whitewashing the Pacific's most famous blackbirder.

Deleuze noted, "It is easy to make fun of Hollywood's historical conceptions" ( 1986, I 49), but did he really have something this easy in mind? It is hard to imagine a film based (exceedingly loosely) on historical characters and events that so earnestly overturns the historical record (can one imagine a World War II film in which the Germans win?). Yet if we are to take Nate and Hayes seriously, we can see the parallel aspects of both monumental and antiquarian history most vividly through the image of 
the Islander, and of course more specifically through the cinematic image of the "Micronesian."

Seemingly based on a few paragraphs in Michener and Day's accounting of Hayes (though not those sections concerned with the slave trade), Nate and Hayes follows Bully as he runs guns for the New Zealand Māori; gives a ride to Nate and Sophie on their way to their new home at an island mission (whereupon Sophie is captured by the dastardly blackbirders led by Hayes's onetime friend and rival Ben Pease, also based on a real historical figure); checks in at the "Port of Samoa"; and finally arrives on the island of Pohnpei (here spelled Ponape). ${ }^{3}$ At the start of the film, in New Zealand, Hayes narrowly escapes a deal gone bad with the female chief of a Māori village, who-adorned with chin tattoo, upright feathers sticking out of her hair, and a complete set of gold teeth-hisses at him, shoots her own sentries for fun (which elicits a rousing bit of laughter from her fellow Islanders), and communicates in grunts interspersed with the Māori word "Pākehā" (foreigner). As Hayes flees across a rickety bridge over a canyon, he confronts four female warriors who scream wildly at him, quickly dispatches the first three with one swing of his staff, and then bests the last woman warrior by punching her in the face and stabbing her with a sword before finally throwing her over the bridge. Perhaps this focus on women Islanders as leaders and soldiers is the filmmakers' way of paying homage to the matrilineal structure of many Pacific Islands societies; more likely, however, in a theme taken up more fully by Anne McClintock (I997), it is an attempt to both feminize and militarize Islanders, who are led by a duplicitous, homicidal woman. The latter seems a reasonable conclusion, as Hayes grouses that "you can't trust a woman" as he is running across the bridge.

The next two island stops suffer from similar distortions of Pacific "free-floating mythology," although to different degrees. After escaping from the shrieking Māori women, Hayes delivers Nate and Sophie to a tropical paradise (appropriately anonymous), peopled with Christianized and (naturally) peace-loving Melanesians, who are ordered around like a group of misbehaving school children by the older, established missionaries. Here the Islanders resemble those of His Majesty O'Keefe's Yap in that they are docile and pay proper obeisance to their white masters, but here the portrayal of Christianization is taken to a parodic extreme as they refer to the missionary's matriarch as "Mama Jesus Christ" and her husband as "Big Man God." Indeed, these Islanders are so smitten with white people that when Hayes's ship approaches shore, they all run 
cheering, smiling, and waving in celebration. (Keep in mind that Hayes was a pirate, and his ship most likely looked quite unlike the ships missionaries normally used for transport.) The contrast between island types could not be clearer: gunrunning Māori led by women cheat and try to kill Bully Hayes, while Christianized Islanders elsewhere can't get enough of his greatness. One wonders if a reasonable representation of Islanders is possible-one that is neither pure aggressor nor mere simpleton, but something in between these extremes (or perhaps on a par with the Westerners they continuously encounter). Thankfully by the time Hayes arrives in the "Port of Samoa," there are no Islanders living on the island-with the exception of those being sold at a slave auction, which Hayes assiduously avoids. (Viewers may be disconcerted by how much this version of "Samoa" looks strikingly like an Old West set from Tombstone, Arizona, complete with a saloon and whorehouse that employs white women.) But even though we are here spared the banality of Pacific stereotypes, the absence of Samoans from "Samoa" echoes the earlier erasure of Yap from His Majesty O’Keefe: Islanders are so cinematically dispensable, it seems, that they don't even have to populate their own islands.

And then, of course, we come to Pohnpei/Ponape-or, as the characters in the film pronounce it, "Pa-Nahpee" (continuing the by now timehonored tradition of mispronouncing, and thus displacing, islands and island names). We are introduced to the island through a brief exchange between the American blackbirder, Ben Pease (played here by Australian actor Max Phipps, which explains his un-American accent), and the German Count Von Rittenberg (played by Grant Tilly, a New Zealand actor who is able to pull off a suitably affected German accent) as they are about to visit the king of Pa-Nahpee to establish German port rights. The count asks, "Why is it so cold?" to which Pease answers, "I wouldn't ask too many questions, Captain. You wouldn't like the answers." The count continues, "I don't like this place." Pease responds, "But it'll still make a fine port for your fatherland, eh? Cold, evil, nasty, but cheap. Bloody strange place." With this last point I will agree: Pa-Nahpee is a bloody strange place, but perhaps that is because I have been to Pohnpei and the first thing one notices on arrival is that the island is anything but cold. Perhaps Pa-Nahpee is cold because the film was shot partly in New Zealand (with the other part filmed in that favorite stand-in for all environments Pacific: Fiji). But climate is the least of this scene's problems: Pease has established for us that the misty, chilly island is "cold, evil, nasty, but cheap," and all we have to do to confirm this is to meet the Islanders. 
The war canoes that confront the German naval vessel are manned by "Pa-Nahpeeans" painted in dark blue from head to toe, who paddle in rhythm to drumbeats and a chant composed of the syllables "yabba yabba." This organized and militaristic group escort Pease and Von Rittenberg to a floating dock that architecturally resembles a Buddhist temple in Thailand (again, we can refer to the panoply of "exotic" props and backgrounds that make watching His Majesty O'Keefe, and especially Nate and Hayes, a dizzying anthropological experience). Once inside, the Westerners are brought to the King of Pa-Nahpee (played by Māori actor and singer Prince Tui Teka), who welcomes them with the following: "Pease-man, what bring? Happy me good now?" Pease, who is fluent in this form of communication, introduces the count: "This be white king. White king bring much gifts." A similar linguistic trick is employed in His Majesty O'Keefe, when O'Keefe arrives at an unnamed island and greets the warriors who meet him on the beach by asking, "Who's that big fella chief?" It is interesting that, while varieties of pidgin flourish in the Pacific (although not in Micronesia), Hollywood writers seem intent on initiating the audience to the language by abolishing established grammar and syntax rules of pidgin and replacing them with a string of words that sound ridiculous as a complete sentence. But again, the point is not to pick on every element of these films that is inaccurate or infuriating, for that would require more space than allotted here, but rather to consider the cinematic images of the Islanders who, in this case, are rather simple in intellect but menacing in appearance.

The king of Pa-Nahpee, we might also note, has razor-sharp teeth and is a cannibal. When we meet him, he is snacking on whatever it is that one would eat out of the top of a human skull, and his currency is both shrunken heads and Western women. Von Rittenberg is thus able to secure the port of Pa-Nahpee for Germany by offering the king said heads as well as Sophie, who is to be sacrificed on an altar at the rim of an active volcano. It seems beside the point here to mention that Pohnpei has no active volcanoes, that the people are not cannibals, and that they do not trade in shrunken heads or white women. Here we turn again to Said, who wrote of Western interpretations of the Muslim world, "we need not look for correspondence between the language used to depict the Orient and the Orient itself, not so much because the language is inaccurate but because it is not even trying to be accurate" (I978, 7I). We cannot concern ourselves with the accuracy of the cinematic image, for it is obvious in this case that the filmmakers did not even consider the possibility of verisimilitude; 
rather, we should understand that the film is not for Pohnpeians but for a Hollywood-loving American audience. The audience needs Pa-Nahpee to be peopled with heathenish cannibals in order for Nate and Hayes to arrive at the last minute and rescue Sophie. The Islanders must be demonized so that the audience will cheer, rather than flinch, when they are shot.

What is most troubling about this film, however, is not its inability to even attempt historical, geographic, or intellectual accuracy; it is that, without knowing anything else about Pohnpei, Pa-Nahpee becomes Pohnpei in the cinematic social imaginary. In his brief analysis of antiquarian historical films, Deleuze warned that even things such as props become "the sign of the actualisation of the epoch. The fabrics become a fundamental element of the historical film" (I986, I 50) - as do shrunken heads, cannibalistic practices, and human sacrifice. Thus Pa-Nahpee as Pohnpei becomes manifest as a "cold, evil, nasty place," and it does so in the absence of Pohnpei, and the rest of the islands of Micronesia, from the social imaginary. As a result, Hollywood inscribes a demonized vision so completely foreign to the Micronesian cinematic subject that it can easily serve as a model for Said's "imaginative geography," one that to date has no filmic counter discourse to challenge it.

\section{On A Desert(ED) IsLAND: Windtalkers (2002)}

When Windtalkers, a film based on the battle of Saipan during World War II, was released in 2002, I remember being particularly excited to see it, as I had lived on the island previously. I went to see the film with a friend from Saipan. We entered the theater eager to see what parts of the island would be featured and how "Saipan" would be treated cinematically; we left the movie disappointed and confused. Like the two films discussed earlier, Windtalkers was not filmed "on location" in Saipan. Moreover, it featured particular landscape elements, such as high desert and scrub brush, that do not even exist on Saipan (or anywhere in the region for that matter), leaving us scratching our heads. Just where was this filmed, and what were the filmmakers trying to tell us about this place, or more specifically, about "Saipan"?

Directed by John Woo, Windtalkers is replete with high-flying grenades, slow-motion falling shell casings, and intricately choreographed hand-tohand combat sequences. Amid all the action, it tells the story of the complex relationship that develops between two marines, Joe Enders (Nicholas Cage) and Pete Anderson (Christian Slater), and the pair of Navajo code 
talkers, Ben Yahzee (Adam Beach) and Charlie Whitehorse (Roger Willie), whom they are assigned to escort. (The Navajo men are employed by the US military to relay messages during the battle of Saipan because the Japanese were unable to interpret the Navajo language.) Enders and Anderson, unbeknownst to Yahzee and Whitehorse, are ordered to kill their Navajo charges rather than let them be captured by the Japanese. In this way, Windtalkers serves as an example of ethical cinematic history, in which the film is concerned with telling the story of American racial and historical injustice toward Native Americans, counterpoised by the willingness and enthusiasm that Native Americans such as Yahzee and Whitehorse displayed in order to "serve our country." Thus, the film "must condemn the injustice of 'things,' bring compassion, herald the new civilisation on the march, in short, constantly rediscover America" (Deleuze I986, I 5 I). In a word, it is a film about the transformative effect World War II had on American society and among ethnic groups; it is not a film about Saipan.

That it is about the battle of Saipan, and not necessarily the battle on Saipan, is clear from the complete absence of Islanders in the film. Perhaps this detail was intentional on the part of Woo: during the fighting in the summer of 1944, most Chamorros and Carolinians hid away in caves in various parts of the island to avoid the heavy shelling and bombing that took place during the American push to take the island. More plausibly, however, Islanders did not factor in the making of the film because this is not their story; indeed, with the focus exclusively on the US Marines and the Navajo code talkers, one wonders if Islanders' stories are worth telling at all. For while it is a trope of modern-day travel agencies to promote Micronesia as the setting for the Pacific War, and indeed to suggest that the history of Micronesia begins and ends with the war, the concern seems to focus entirely on the various American and Japanese contingencies involved; if Islanders appear at all in these narratives, they do so only as additional scenery.

An aspect of this erasure of Islanders can be seen as the Windtalkers credits roll and one notices that three characters are named after the local village in which they appear: "Tanapag mother," "Tanapag girl," and "Tanapag boy." Each of these characters, however, is a Japanese colonist, not an Islander from Tanapag (echoing a similar ploy in which the Japanese substitute for native Islanders in the much earlier, yet equally problematic film, Hell to Eternity). Here the filmmakers appear to have missed a perfect opportunity to consider the striking parallels between Native Americans and Micronesians, or more specifically between Navajo 
and Chamorro. One obvious similarity is the current subjugation of both groups under the aegis of the US Department of Interior, and what that arrangement means for American social conceptions of Micronesia in general as a sort of new Western frontier, or perhaps even a newly imagined "manifest destiny." In recognizing the absence of Islanders in this context, then, we see how both their displacement from Saipan and their subsequent replacement by the historical image of the Native American as "noble savage" are instructive for understanding one rather conspicuous way in which Chamorros have been erased-both from the film and from the American historical imaginary.

The landscape also bears out Windtalker's purpose as a story about America rather than Saipan, as it was filmed on the island of O'ahu and in southern California; we are therefore treated to stunning views of sheer tropical cliffs rising out of the ocean and interior plateaus of high desert vegetation. While Saipan is anything but a desert environment, the arid and dusty "Saipan" in the film is necessary to link the story of the code talkers with their role in the Pacific Theater during the war: at the end of the film we transition seamlessly from the desolate windswept hills of "Saipan" to the barren yet instantly recognizable Arizona desert of Monument Valley, the home of Yahzee and Whitehorse. Were "Saipan" to be recognizable as a humid, tropical island thick with greenery and sultry foliage, the connection between the code talkers' role and their place in the imaginary of the American West would not be made as easily by the audience, and the film would fail as ethical history.

A useful contrast to "Saipan" comes in the beginning of the film, in which Enders is leading his unit through the jungles of the Solomon Islands; here the island scene is replete with low-hanging rain forest trees and freshwater streams, and one can almost see the steam rising from the earth. This setting is clearly meant to serve as a visual cue that the Solomons are hot, sticky, and covered in dense foliage-allowing for a claustrophobic battle scene in which the Japanese can be hiding almost anywhere. It is also a striking counterexample to another film set (and filmed) in the Solomons, Terrence Malick's The Thin Red Line (r998), in which the landscape portrays "a nature that is alive and resonating" (Shapiro 2009, I4I). Rather than use the landscape as another character in Windtalkers, however, Woo uses it merely as a set piece; the only reference to the Solomons comes from Enders, who describes it as "a shitty swamp marsh on the ass-end of nowhere." No mention is made of the uninhabited deserts of "Saipan," and it is precisely this loss of the landscape-as-character that 
alienates the film from its supposed "location." Indeed, it may be difficult to think of a greater contrast in directorial styles than those of Malick and Woo regarding the use of the landscape; in The Thin Red Line it plays a significant role in locating the deeper problematics of being in nature and in the world (Shapiro 2009), while in Windtalkers the landscape is merely present as the staging area for what is essentially an action film.

In Windtalkers, however, a greater inconsistency than its mere location is at work, and that lies in Woo's efforts at realism. In a marked departure from his earlier days as a director in Hong Kong, and even from his initial forays into Hollywood, Woo seemingly attempted to offer a historical-realist approach to Windtalkers: "the filmmakers received full support from the US Department of Defense, and sent Captain Matt Morgan of the Marines to assist. ... All of the weapons were authentic, and events depicted were accurate (and therefore familiar). Code talker Albert Smith, who fought on Saipan when he was only I 5 years old, confirmed everything. Realism and authenticity were highly valued" (Stokes 2004, I88). Woo also had a Japanese advisor, "Dan King, to advise them on all things Japanese, including the language" (Stokes 2004, I97). Yet despite all this effort, the location of the shoot lends itself to many things, but not to realism. We should return for a moment to Deleuze's statement that realism "produced the universal triumph of the American cinema, to the point of acting as a passport for foreign directors who contributed to its formation" (I986, I4 I). Certainly Woo here has endeavored to faithfully recreate the battle of Saipan-while omitting a "minor detail": Saipan itself. Even the brief cartographic military images of Saipan used to track the advance of US troops to the northern end of the island (like the map of "Yap" in His Majesty O'Keefe) do little more than establish "Saipan" as a "lacunary or isolated 'fact"” (Conley 2007, 20). Realism, then, in the case of Windtalkers, excludes the actual island, omits Islanders, and argues that we need not concern ourselves with where the film is shot, only that its ethical historical accuracy remains intact. It is realistic insofar as the audience believes that all islands are the same and that leeward $\mathrm{O}^{\prime}$ ahu and southern California are suitable stand-ins for the cinematic subject that is "Saipan."

\section{Fade Out}

We would do well here to return to the rules of Hollywood's "Micronesia" and consider what it is that is displaced from and inscribed on 
the islands as cinematic text. Certainly it is reasonable to suggest that both Islanders and islands are missing: the Islanders, if they appear at all, are erased and written over, replaced with mute love interests and chiefs, gibberish-spewing cannibals, and other dispensable figurations; and while the islands exist cartographically, geographically they are present as parts of a Pacific-anywhere. In short, the Islanders and their islands are apparent only in their absence, and it is in this absence that Hollywood produces a set of truths by practicing its own conceptions of realism through monumental, antiquarian, and ethical histories.

It is also important to note that these histories are the stories of Americans, as mediated through the experiences of white American men. The stories of the Islanders themselves do not matter. At stake in the cases of His Majesty O'Keefe and Nate and Hayes are the hero's interactions with the island-other, or in Windtalkers, with other characters in the American historical narrative such as the Navajo and the Japanese. Thus the Islanders, their histories, and their cultures are interchangeable: Yapese are Fijians, Fijians are Palauans, Māori are Pohnpeians, and so on. It is telling that no Micronesians appear as actors or extras in these films, nor are any of the region's languages employed, with the exception of place-names (almost all of which are mispronounced). Micronesians need not exist in the cinematic imaginary; in fact, it is easier if they do not, as Hollywood is then able to write over this de-positioned text with romantic, demonic, or other stereotypical Pacific ideals to suit the purposes of its method, which is the project of American history. The more exotic its reinscription, it seems, the better.

But if we are to imagine for a moment that Micronesians themselves are a part of Hollywood's moviegoing audience, what then are Islanders supposed to relate to in the foregoing representations? Is the intention for Micronesians to identify with their own displacement? Writing about African film audiences watching European and American movies during colonial rule, Rodowick argued, "On the one hand, it alienated Africans from the image of black skin, leaving no place with which to identify save with the idealized image of their oppressors. On the other, it homogenized the diversity and complexity of African cultures" (I997, I 59). Similarly, Hollywood's treatment of Micronesia has done little to provide a counter discourse on representations of Islanders in film, nor has it treated the variety, density, or intricacy of Micronesian cultures in any meaningful way.

Likewise, the geography of the islands is displaced, allowing Saipan 
to display its arid rolling hills growing cacti and Pohnpei to exhibit raging volcanoes and towering New Zealand pine trees. Perhaps we should not be surprised by this conflation of ecologies and environments, since none of the films considered here was shot in Micronesia. Rather, Hollywood seems content to use such diverse (non-Micronesian) settings as Polynesia, Melanesia, and even southern California, thereby dislodging Micronesian islands as actual, accessible locations. By displacing not just Islanders but the very islands themselves, Hollywood inverts a tradition of Micronesia-as-absence that was initiated at least as far back as I 832 by Dumont d'Urville: Micronesia was originally carved out of what Polynesia and Melanesia were not, while Hollywood has similarly upended Micronesia by representing the region as mediated through Polynesian and Melanesian actors, languages, set designs, and locations. In the social imaginary, moreover, Micronesia-as-absence has largely erased the islands and people from their role in US history. Not many Americans are aware of the creation of American Micronesia as an area of strategic military denial (another form of absence) following World War II, or of the role that the islands, particularly those in the Marshalls group, played in nuclear testing (creating yet another form of absence through the dislocation of the inhabitants of nuclear-affected atolls).

Perhaps it is useful to end by revisiting Deleuzean fabulation, the process by which a people produce a "collective enunciation" through cinema. More than simply "storytelling," fabulation is an act-oral, written, or visual-that requires "a transformation of both language and point of view" (Rodowick I997, I6I). Moreover, this act serves as an affirmative will to power, one in which a people employs a minority discourse in the service of "becoming" on its own terms and according to its own definitions. While the minor cinema of the Micronesian region has a long way to go to realize its own becoming through will to power, some promising alternative cinematic discourses are emerging in the Marshall Islands. Indeed, the suggestion that there is a "Micronesian" minor cinema may in itself play into the colonial determination of what we mean by "Micronesia"; we might be better served thinking in terms of "Marshallese" minor cinema, if only to re-place the Marshalls in their own context. As mentioned earlier, Morning Comes So Soon is a breakthrough of sorts in Marshallese fabulation, as the film was shot entirely in Majuro and is mostly in the Marshallese language. Although the film was written, produced, and directed by American expatriates living in the Marshall Islands, as an initial effort it has done more to re-place and re-locate Islanders and 
their islands than anything yet produced by Hollywood. Indeed, the plot of the film-which centers on the development of a romantic relationship between a Marshallese boy and a Chinese girl, and on the ensuing racial tensions that are reflective of the contemporary social climate in Majuro-perhaps goes even further in redefining what it means to be an "Islander" by juxtaposing the experiences of indigenous Marshallese people with those of immigrant Chinese residents.

In a related example, the 2008 film Ña Noniep (I am the Good Fairy) tells the story of two Marshallese students whose relationship is threatened, and then restored, through what the filmmaker terms "black magic." Setting aside such questionable terminology, the comparatively less sophisticated technical production (at least compared to that of Morning Comes So Soon), and the fact that the film was written, produced, and directed by (again) an American expatriate living in the islands, the recognition and use of local knowledges as a legitimate plot device offers the possibility of telling a cinematic story from perspectives other than those produced by Hollywood studios. What makes this example problematic, however, especially in comparison to Morning Comes So Soon, is the way in which it is presented to the general (and largely Marshallese) public; specifically, one wonders why the two recommendations on the DVD jacket material come solely from Americans-one a college professor from the US continent, the other the US ambassador to the Marshall Islands at the time of the film's release. Additionally, it is not clear what is meant by the ambassador's comment that the movie "should nurture a sense of pride and self-worth among the Marshallese people," other than implying that, without this film, the Marshallese are somehow lacking in pride and selfworth. Such paternalistic recommendations seem to work against the very idea of the development of minor cinema in this context and counteract what is an otherwise novel approach to widening a cinematic counter discourse in the islands.

Nevertheless, the development and proliferation of similar (and, one hopes, increasingly progressive) examples of minor cinema in the region, especially those mediated through the lenses of the Islanders themselves, will require us to look differently on the Island contexts they represent, and on the discursive constructions that make up "Micronesia," so that we may appreciate the whole, diverse range of cultures, peoples, and islands. As Rodowick put it, such a cinematic will to power, through the realization of a minor cinema, hinges "on the basis of which a people can invent themselves" (I997, I 53). Otherwise, if popular cinematic constructions 
of the region focus only on its absence, on its summary displacement in favor of the hole that is Micronesia in the social imaginary, we may be left with a filmic subjectification on which Hollywood continues to inscribe a "Micronesia" that is altogether unrecognizable.

THIS ESSAY BEGAN as a short reaction paper in a History of Micronesia seminar I took with David Hanlon in fall 2008, and was expanded in a Writing Politics class I took with Michael J Shapiro in spring 2009, both at the University of Hawai'i at Mānoa (UHм). I would like to thank both David and Michael for providing the academic and intellectual inspiration for this article, as well as Hannah $M$ Tavares of the Uнм Department of Educational Foundations for her insightful comments. In addition, I would like to thank the managing editor of this journal for her patience and assistance, along with the two anonymous reviewers, for helping to make this work publishable.

\section{Notes}

I The use of Filipino actors helps explain the native fluency of the "Chamorros" in Tagalog throughout the film.

2 For a more comprehensive but somewhat dated and therefore not quite exhaustive list of documentaries about Micronesia, see Mellon I994; see also Mawyer 1998 (and an updated version of the latter database online: http://www .hawaii.edu/oceanic/film/).

3 Ponape was the official spelling of the island state in 1983 , a year before the Federated States of Micronesia's legislature changed it to its current iteration, or rather, restored its original spelling, Pohnpei.

\section{References}

Conley, Tom 2007 Cartographic Cinema. Minneapolis: University of Minnesota Press. Crowther, Bosley

I954 Screen in Review: Burt Lancaster Stars in "His Majesty O'Keefe," a South Seas Tale of Adventure. New York Times, 6 February.

Deleuze, Gilles

I986 Cinema I: The Movement-Image. Minneapolis: University of Minnesota Press.

Derrida, Jacques

198 I Dissemination. Chicago: University of Chicago Press. 
Hanlon, David

I989 Micronesia: Writing and Rewriting the Histories of a Nonentity. Pacific Studies I 2 (2): I-2I.

2006 On Hezel's The First Taint of Civilization. In Texts and Contexts: Reflections in Pacific Islands Historiography, edited by Doug Munro and Brij V Lal, 202-2 I 2. Honolulu: University of Hawai'i Press.

2009 The "Sea of Little Lands": Examining Micronesia's Place in "Our Sea of Islands." The Contemporary Pacific 2I:9I-I IO.

Hezel, Francis X

I983 The First Taint of Civilization: A History of the Caroline and Marshall Islands in Pre-colonial Days, I52I-I885. Pacific Islands Monograph Series I. Honolulu: University of Hawai'i Press.

2008 The Man Who Was Reputed to Be King: David Dean O'Keefe. The Journal of Pacific History 43 (2): 239-252.

Horne, Gerald

2007 The White Pacific: US Imperialism and Black Slavery in the South Seas After the Civil War. Honolulu: University of Hawai'i Press.

Klingman, Lawrence, and Gerald Green

I950 His Majesty O’Keefe. Honolulu: Mutual Publishing.

Mawyer, Alexander

I998 Moving Images of the Pacific Islands: A Guide to Films and Videos. CPIS Occasional Paper 38. Honolulu: Center for Pacific Islands Studies.

McClintock, Anne

I997 “No Longer in a Future Heaven”: Gender, Race and Nationalism. In Dangerous Liaisons: Gender, Nation, and Postcolonial Perspectives, edited by Anne McClintock, Aamir Mufti, and Ella Shohat, 89-I I 2. Minneapolis: University of Minnesota Press.

Mellon, James

I994 Representations of Micronesia on Film, Video, and Television. EastWest Film Journal 8 (I): 86-I 20.

Michener, James A, and A Grove Day

I957 Rascals in Paradise. New York: Random House.

Nietzsche, Friedrich

I997 On the Uses and Disadvantages of History for Life. In Nietzsche: Untimely Meditations, edited by Daniel Breazeale, 57-I 23. Cambridge, UK: Cambridge University Press.

Rainbird, Paul

2003 Taking the Tapu: Defining Micronesia by Absence. The Journal of Pacific History 38 (2): 237-250.

Rodowick, David N

I997 Gilles Deleuze’s Time Machine. Durham, nc: Duke University Press. 
Said, Edward W

I978 Orientalism. New York: Vintage Books.

Shapiro, Michael J

2009 Cinematic Geopolitics. New York: Routledge.

Stokes, Lisa O

2004 John Woo's War: Real (Reel) Dreams, Windtalkers, and the Hollywood Machine. Asian Cinema I 5 (Spring/Summer): I87-202.

Tcherkézoff, Sergei

2003 A Long and Unfortunate Voyage towards the "Invention" of the Melanesia/Polynesia Distinction I 595-1832. The Journal of Pacific History 38 (2): 175-196.

Teaiwa, Teresia K

2000 bikinis and other s/pacific n/oceans. In Voyaging through the Contemporary Pacific, edited by David Hanlon \& Geoffrey M White, 9I-I I 2. Lanham, MD: Rowman \& Littlefield. First published in The Contemporary Pacific 6:87-109.

Telegraph [London]

200I Tessa Welborn. The Telegraph, 23 July. http://www.telegraph.co.uk/ news/obituaries/I334923/Tessa-Welborn.html [accessed I 5 April 2009]

\section{Films and Videos Cited}

Condon, Aaron, and Mike Cruz, screenwriters and directors

2008 Morning Comes So Soon. Feature film. Color, 8I minutes. Screenplay by Aaron Condon, Mike Cruz, and Tara Condon; produced by Aaron Condon. Majuro, Marshall Islands: Small Island Films.

Dobkin, David, director

2005 Wedding Crashers. Feature film. Color, I I 9 minutes. Written by Steve Faber and Bob Fisher; produced by Peter Abrams, Robert L Levy, and Andrew Panay. Hollywood: New Line Cinema.

Fairfax, Ferdinand, director

I983 Nate and Hayes. Feature film. Color, 99 minutes. Screenplay by John Hughes and David Odell; produced by Lloyd Phillips and Rob Whitehouse. Hollywood: Paramount Pictures.

Ford, John, producer and director

I962 The Man Who Shot Liberty Valance. Feature film. Black and white, I23 minutes. Screenplay by James Warner Bellah and Willis Goldbeck; produced by Willis Goldbeck and John Ford. Hollywood: Paramount Pictures.

Goldstone, Richard, and John Monks Jr, writers, producers, and directors I962 No Man Is an Island. Feature film. Color, I I4 minutes. Hollywood: Gold Coast Productions. 
Haskin, Byron, director

I953 His Majesty O’Keefe. Feature film. Color, 90 minutes. Screenplay by Borden Chase and James Hill; produced by Harold Hecht. Hollywood: Warner Brothers Pictures.

Honda, Ishirō, writer and director

I954 Gojira. Feature film. Black and white, 98 minutes. Screenplay by Ishirō Honda, Shigeru Kayama, and Takeo Murata; produced by Tomoyuki Tanaka. Tokyo, Japan: Toho Film Company.

Honda, Ishirō, and Terry O Morse, directors

I956 Godzilla, King of the Monsters! Feature film. Black and white, 80 minutes. Screenplay by Ishirō Honda, Shigeru Kayama, Takeo Murata, and Al C Ward; produced by Edward B. Barison, Richard Kay, Joseph E Levine, Harry Rybnick, Tomoyuki Tanaka, and Terry Turner. Boston: Embassy Pictures Corporation; Hollywood: TransWorld Releasing; Tokyo: Toho Film Company.

Karlson, Phil, director

I960 Hell to Eternity. Feature film. Black-and-white, I32 minutes. Screenplay by Ted Sherdeman and Walter Roeber Schmidt; produced by Irving H Levin. Hollywood: Atlantic Pictures.

Lee, Malcolm D, writer and director

2008 Welcome Home Roscoe Jenkins. Feature film. Color, I I 4 minutes. Produced by Charles Castaldi, Mary Parent, and Scott Stuber. Hollywood: Universal Pictures.

Malick, Terrence, screenwriter and director

I998 The Thin Red Line. Feature film. Color, I70 minutes. Produced by Robert Michael Geisler, John Roberdeau, and Grant Hill. Hollywood: Fox 2000 Pictures.

Niedenthal, Jack, writer, producer, and director

$2008 \tilde{N} a$ Noniep. Feature film. Color, Io8 minutes. Majuro, Marshall Islands: Microwave Films.

Pyun, Albert, director

2004 Max Havoc: Curse of the Dragon. Feature film. Color, 90 minutes. Screenplay by Irina Diether; produced by Yoram Barzilai, Melissa Ciampa, and Connie Dolphin. Hagåtña: Guam Motion Pictures Company.

Sholder, Jack, director

200 I Arachnid. Feature film. Color, 95 minutes. Written by Mark Sevi; produced by Julio Fernández and Brian Yuzna. Barcelona, Spain: Castelao Producciones.

Stiller, Ben, writer, producer, and director 200I Zoolander. Feature film. Color, 89 minutes. Written by Drake Sather 
and Ben Stiller; produced by Ben Stiller, Stuart Cornfeld, and Scott Rudin. Hollywood: Paramount Pictures.

Stone, Robert, producer and director

I988 Radio Bikini. Documentary. Color and black-and-white, 56 minutes. New York: Robert Stone Productions.

Woo, John, producer and director

2002 Windtalkers. Feature film. Color, I34 minutes. Written by John Rice and Joe Batteer; produced by John Woo, Terence Chang, Tracie Graham, and Alison Rosenzweig. Hollywood: Metro-Goldwyn-Mayer Pictures.

\section{Abstract}

The subject of "Micronesia" has rarely figured in Hollywood's cinematic lexicon, but when it does it is usually relegated to the exotic backdrop of the familiar colonial screen. By employing two Deleuzean cinema analytics that consider realism as well as monumental, antiquarian, and ethical historical representations in film, I closely "read" three Hollywood movies spanning fifty years of subjectivizing "Micronesia" in the social cinematic imaginary. Such a reading of His Majesty O’Keefe (1953), starring Burt Lancaster and set in Yap; Nate and Hayes (1983), starring Tommy Lee Jones and set partially in Pohnpei; and Windtalkers (2002), starring Nicholas Cage about the battle of Saipan, allows us to consider both the various "truths" about Micronesia that Hollywood produces and what the functions of those truths are. Finally, the paper takes into account Deleuze's conception of minor cinema as well as his notion of fabulation in order to offer a counter discourse to the popular Hollywood displacement of "Micronesia" both from the public imaginary and from the islands and Islanders themselves.

KEYWORDS: Micronesia, film, representation, Hollywood, Gilles Deleuze, minor cinema 